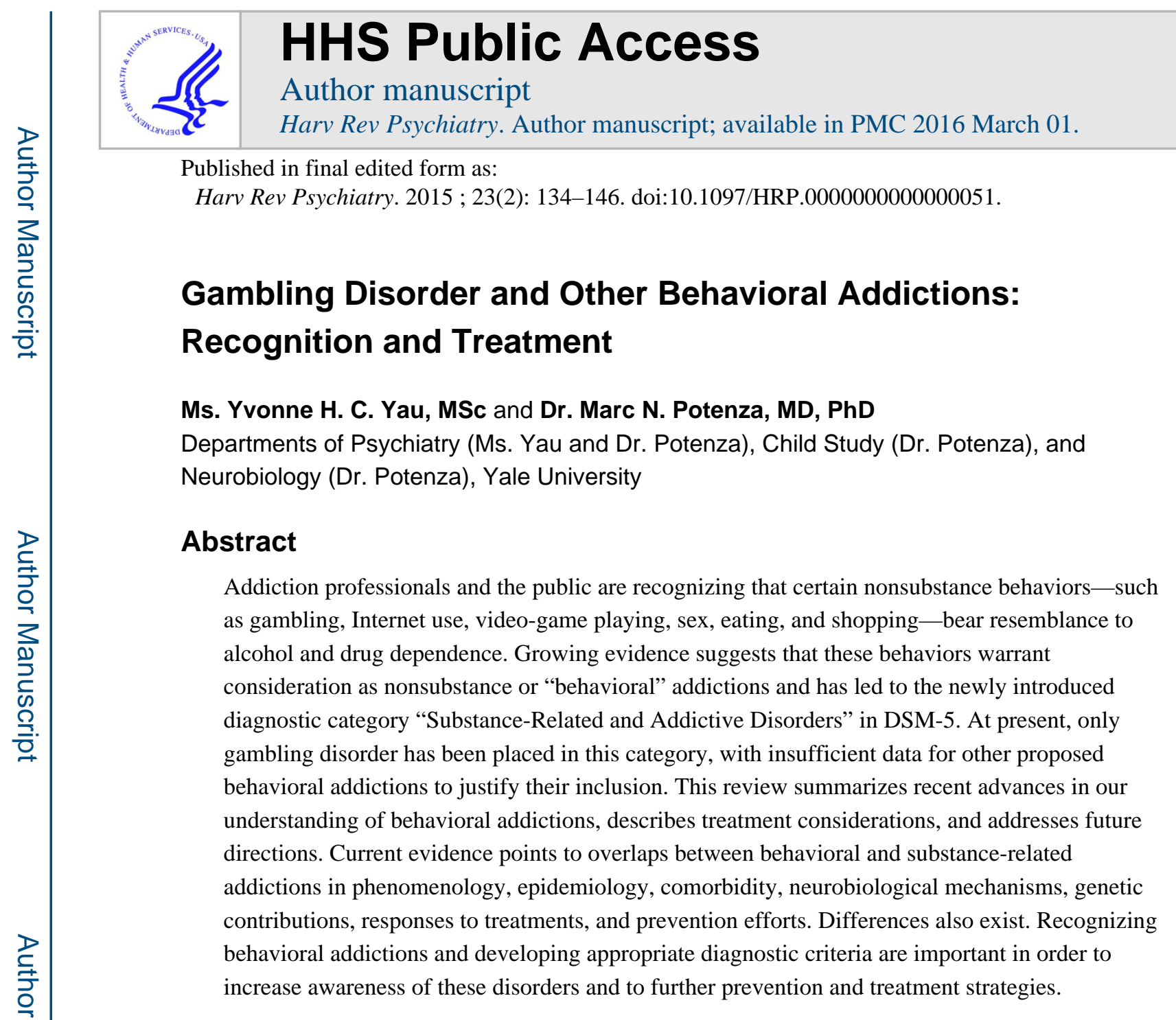

Keywords

behavioral addiction; diagnosis; disordered gambling; Internet gaming disorder; neurobiology

\begin{abstract}
Addiction has been proposed to have several defining components: (1) continued engagement in a behavior despite adverse consequences, (2) diminished self-control over engagement in the behavior, (3) compulsive engagement in the behavior, and (4) an appetitive urge or craving state prior to engaging in the behavior. ${ }^{1-3}$ Although, for a period of time, the term addiction was almost exclusively used to refer to excessive and interfering patterns of alcohol and drug use, the Latin word (addicere) from which it derived did not originally have this import. ${ }^{4}$ Researchers and others have recently recognized that certain behaviors resemble alcohol and drug dependence, and they have developed data indicating
\end{abstract}

Correspondence: Marc N. Potenza, PhD, MD, Room 726, 1 Church St., New Haven, CT 06510. marc.potenza@yale.edu.

Declaration of interests: Potenza has consulted for Lundbeck, Ironwood, Shire, and INSYS pharmaceuticals and RiverMend Health; received research support from Mohegan Sun Casino, Psyadon Pharmaceuticals, and National Center for Responsible Gambling; has participated in surveys, mailings, or telephone consultations related to drug addiction, impulse-control disorders, or other health topics; and has consulted for gambling, legal, and governmental entities on issues related to addictions or impulse-control disorders. The funding agencies did not provide input or comment on the content of the manuscript, which reflects the contributions and thoughts of the authors and not necessarily the views of the funding agencies. 
that these behaviors warrant consideration as nonsubstance or "behavioral" addictions. , $^{1,5,6}$ The concept remains controversial. Excessive engagement in behaviors such as gambling, Internet use, video-game playing, sex, eating, and shopping may represent addictions. ${ }^{7}$ A significant minority of individuals who show such excessive behavior display habitual or compulsive engagement. ${ }^{8,9}$

Several converging lines of evidence show an overlap between these conditions and substance dependence in terms of clinical expression (e.g., craving, tolerance, withdrawal symptoms), comorbidity, neurobiological profile, heritability, and treatment. ${ }^{9}{ }^{910}$ Moreover, behavioral and substance addictions share many features in natural history, phenomenology, and adverse consequences. Both forms of addiction typically have onsets in adolescence or young adulthood, with higher rates observed in these age groups than among older adults. ${ }^{11}$ Both forms of addiction have natural histories that may exhibit chronic and relapsing patterns, and in both forms, many people recover on their own without formal treatment. ${ }^{12}$

Much remains to be understood, however, in the relatively novel field of behavioral addictions. Additionally, wide gaps exist between research advances and their application in practice or public policy settings. This lag is due, in part, to the public perception of behavioral addictions. Whereas drug abuse has well-known and severe negative consequences, those associated with behavioral addictions (e.g., dysfunction within the family unit, ${ }^{13,14}$ incarceration, ${ }^{15}$ early school dropouts, ${ }^{16}$ financial troubles ${ }^{17,18}$ ) are often overlooked despite tremendous implications for public health. Moreover, because engagement in some behaviors with addictive potential is normative and adaptive, individuals who transition to maladaptive patterns of engagement may be considered weak willed and be stigmatized. Thus, research, prevention, and treatment efforts must be furthered, and educational efforts enhanced.

\section{DSM-5 CONSIDERATIONS}

Establishing nomenclature and criteria for behavioral addictions will enhance our capacity to recognize and define their presence. In the recently released fifth edition of the Diagnostic and Statistical Manual of Mental Disorders (DSM-5), ${ }^{19}$ a major modification is the reclassification of pathological gambling (renamed "disordered gambling") from the "Impulse Control Disorders Not Elsewhere Classified" category into the new "SubstanceRelated and Addictive Disorders" category. The new term and category, and their location in the new manual, lend additional credence to the concept of behavioral addictions; people may be compulsively and dysfunctionally engaged in behaviors that do not involve exogenous drug administration, and these behaviors can be conceptualized within an addiction framework as different expressions of the same underlying syndrome. ${ }^{2}$ Although disordered gambling is the only addictive disorder that is included in the main section of DSM-5, several other conditions have been included in Section III- the part of DSM-5 in which conditions that require further study are located. In particular, the DSM-5 work group has flagged "Internet gaming disorder" as a possible candidate for future inclusion in the addictions category. Although the inclusion of this disorder in the provisional diagnosis section of DSM-5 represents an important advance, the conflation of problematic Internet use and problematic gaming may prove unhelpful; the result may be gaps in research on 
problematic Internet use that is unrelated to gaming (e.g., social networking) or on problematic gaming that is unrelated to Internet use. ${ }^{20}$

This review will highlight the recent neurobiological, genetic, and treatment findings on behavioral addictions. An emphasis will be placed on disordered gambling since it is arguably the best-studied behavioral addiction to date. Other behavioral addictions, despite being less well studied, have been receiving considerable attention from researchers and clinicians and will also be discussed in this review. We will then discuss the similarities and differences between behavioral and substance-related addictions.

\section{METHODS}

A literature search was conducted using the PubMed database for articles in English pertaining to behavioral addictions. Case reports and studies with insufficient statistical information were excluded from this review. Because of the overlapping terms used to describe each condition, search items included the many different names found in the literature. For example, searches were made for "Internet addiction," "compulsive Internet use," and "problematic Internet use." It is noteworthy that the sample sizes in most of the studies cited in this review are small and that the criteria used to define diagnoses vary between studies. These methodological differences should be considered when interpreting the findings.

\section{PHENOMENOLOGY AND EPIDEMIOLOGY}

Disordered gambling can include frequent preoccupations with gambling, gambling with greater amounts of money to receive the same level of desired experience (tolerance), repeated unsuccessful efforts to control or stop gambling, restlessness or irritability when trying to stop gambling (withdrawal), and the interference of gambling in major areas of life functioning. Criteria also include gambling to escape from a dysphoric state, gambling to regain recent gambling-related losses ("chasing" losses), lying in significant relationships about gambling, and relying on others to fund gambling. One major change in the DSM-5's clinical description of gambling disorders is that it eliminated the requirement that a person engage in illegal activities to finance gambling. ${ }^{19}$ Additionally, the threshold of inclusionary criteria was reduced from 5 of 10 to 4 of 9 ; this new threshold is thought to improve the classification accuracy and reduce the rate of false negatives. However, the contrast in the thresholds for gambling disorder (4 of 9 criteria) and substance use disorders (SUDs; 2 of 11 criteria) will likely underestimate the relative prevalence and impact of gambling disorder. Epidemiological studies that have employed screening instruments like the South Oaks Gambling Screen ${ }^{21}$ have frequently generated higher prevalence estimates than have those employing DSM criteria. ${ }^{20,22,23}$ Meta-analytic data suggest that prevalence of past-year adult disordered gambling is between $0.1 \%$ to $2.7 \% .^{24}$ The estimated proportion of disordered gamblers among college students appears higher, estimated in one study at $7.89 \% .25$

Definitions of other behavioral addictions have often used DSM criteria for disordered gambling as a blueprint. ${ }^{26,27}$ For example, Young's Diagnostic Questionnaire ${ }^{28}$ proposes 
the following criteria for Internet addiction: withdrawal, tolerance, preoccupation with the Internet, longer than intended time spent on the Internet, risk to significant relationships or employment relating to Internet use, lying about Internet use, and repeated, unsuccessful attempts to stop Internet use. However, sample and measurement differences, coupled with the lack of universally agreed-upon diagnostic criteria, may contribute to variable prevalence estimates for Internet addiction. Estimates for adolescents have ranged from $4.0 \%$ to $19.1 \%$, and for adults, from $0.7 \%$ to $18.3 \% .{ }^{29}$ Similarly, a range of prevalence estimates (with criteria mostly based on those for disordered gambling) have been reported for problematic video-game playing among adolescent populations (4.2\%-20.0\%), with adult estimates (11.9\%) also falling in that range. ${ }^{29}$

\section{CO-OCCURRING DISORDERS}

Data from the U.S. National Comorbidity Survey Replication-a U.S.-based community survey with 9282 respondents-reported that $0.6 \%$ of respondents met criteria for lifetime disordered gambling (2.3\% reported at least one inclusionary criterion); of those, $96 \%$ met critieria for at least one other lifetime psychiatric diagnosis, and $49 \%$ had been treated for another mental illness. ${ }^{30}$ High co-occurrence rates between behavioral and substance addictions have been observed; a recent meta-analysis suggest a mean co-occurrence of $57.5 \%$ between disordered gambling and substance addiction. ${ }^{24}$ Among individuals with SUDs, the odds of disordered gambling were elevated almost threefold. ${ }^{31}$ Conversely, the odds for an alcohol use disorder increased roughly fourfold when disordered gambling was present. ${ }^{32}$ Clinical samples of other behavioral addictions suggest that co-occurrence with SUDs is common. ${ }^{33}$ In a study of 2453 college students, individuals meeting the criteria for Internet addiction were roughly twice as likely to report harmful alcohol use, after controlling for gender, age, and depression. ${ }^{34}$ Taken together, these findings suggest that behavioral addictions may share a common pathophysiology with SUDs. ${ }^{10}$

Disordered gambling also frequently co-occurs with various psychiatric conditions, including impulse-control, mood, anxiety, and personality disorders. ${ }^{8,23,35,36}$ It has been suggested that mood and anxiety disorders precede gambling problems, ${ }^{30}$ which may manifest as a maladaptive coping mechanism. ${ }^{37}$ Longitudinal studies suggest, however, that disordered gambling is associated with incident (new onset) mood disorders, anxiety disorders, and SUDs, ${ }^{38}$ with incident SUDs being moderated by gender. ${ }^{39}$ Additionally, both incident medical disorders and incident mental health disorders are related to disordered gambling, particularly among older adults..$^{39,40}$ The presence or absence of specific co-occurring conditions is important to consider when selecting treatment strategies. ${ }^{41}$

\section{DATA LINKING BEHAVIORAL AND SUBSTANCE ADDICTIONS}

Especially relevant to addictions are aspects of motivation, reward processing, and decision making. ${ }^{42-44}$ These features represent potential endophenotypes, or intermediate phenotypes, that could be pursued in biological investigations across a spectrum of substance- and non-substance-related addictive disorders and may serve as possible markers for prevention and treatment efforts. ${ }^{45}$ 


\section{Personality}

Individuals with behavioral and substance addictions score high on self-report measures of impulsivity and sensation seeking, and generally low on measures of harm avoidance. ${ }^{46,47}$ Some data indicate, however, that individuals with Internet addiction, problematic videogame playing, or disordered gambling may exhibit high levels of harm avoidance, ${ }^{29,48}$ suggesting important individual differences among people with addictions. The extent to which behavioral tendencies like harm avoidance may shift (e.g., over time) or differ (e.g., according to geographic region or other factors) warrants additional research.

Other research suggests that aspects of compulsivity are typically higher among individuals with behavioral addictions. ${ }^{31,49}$ Consequently, some conceptualize behavioral addictions along an impulsive-compulsive spectrum. ${ }^{50}$ Compulsivity represents a tendency to repeatedly perform acts in a habitual manner to prevent perceived negative consequences, though the act itself can lead to negative consequences. ${ }^{51}$ While both impulsivity and compulsivity imply impaired impulse control, recent data suggest a more complex relationship between these two constructs as they relate to obsessive-compulsive disorders (OCDs) and behavioral addictions. For example, although groups with disordered gambling or with OCD both score highly on measures of compulsivity, among disordered gamblers these impairments appear limited to poor control over mental activities and to urges and worries about losing control over motor behaviors. ${ }^{52}$ By contrast, OCD subjects tend to score poorly across most domains. ${ }^{53}$

\section{Neurocognition}

Neurocognitive measures of disinhibition and decision making have been positively associated with the severity of problem gambling ${ }^{54}$ and may predict relapse of disordered gambling. ${ }^{55}$ Similar to individuals with SUDs, individuals with disordered gambling have displayed impairments in risky decision making and in reflection impulsivity in comparison to matched control subjects. ${ }^{56}$ Disadvantageous performance on the Iowa Gambling Task, which assesses risk/reward decision making, has been observed among individuals with disordered gambling and alcohol dependence ${ }^{57}$ In contrast, a study of individuals with Internet addiction did not demonstrate such deficits in decision making on the Iowa Gambling Task. 58

Attempts to control or eliminate addictive behaviors may be motivated by immediate reward or the delayed negative consequences of use-that is, temporal or delay discounting. This process may be mediated via diminished top-down control of the prefrontal cortex over subcortical processes promoting motivations to engage in addictive behavior. ${ }^{59}$ Individuals with disordered gambling and SUDs display rapid temporal discounting of rewards; in other words, they are more prone to select smaller, earlier rewards than larger ones that come later. ${ }^{60,61}$ Although some data suggest that abstinent individuals with SUDs perform better (display less delay discounting) than do individuals with current SUDs, other data suggest no significant differences. ${ }^{60} \mathrm{~A}$ recent study suggests that delay discounting did not differ in individuals with disordered gambling pretreatment and one-year posttreatment. ${ }^{62}$ 


\section{Neurochemistry}

Dopamine has been implicated in learning, motivation, salience attribution, and the processing of rewards and losses (including their anticipation [reward prediction] and the representation of their values). ${ }^{63}$ Given the importance of dopaminergic projections in reward circuits-including projections from the ventral tegmental area to ventral striatum in SUDs ${ }^{63}$ - studies on behavioral addictions and related behaviors have focused on investigating dopamine transmission. A recent single-photon emission computed tomography study suggests that dopamine release in the ventral striatum during a motorbikeriding computer game ${ }^{64}$ is comparable to that induced by psychostimulant drugs such as amphetamine ${ }^{65}$ and methylphenidate. ${ }^{66}$ In one small study using positron emission tomography with the tracer $\left[{ }^{11} \mathrm{C}\right]$ raclopride, dopamine release in the ventral striatum was associated positively with Iowa Gambling Task performance in healthy control subjects but negatively in individuals with disordered gambling, ${ }^{67}$ suggesting that dopamine release may be involved in both adaptive and maladaptive decision making. Although a gambling task induced no differences in the magnitude (i.e., $\left[{ }^{11} \mathrm{C}\right]$ raclopride displacement) between disordered gamblers and controls, among disordered gamblers dopamine release correlated positively with problem-gambling severity ${ }^{68}$ and with subjective excitement. ${ }^{69}$

Similar to individuals with SUDs,${ }^{70}$ reduced D2/D3 receptor availability in the striatum has been observed in individuals with Internet addiction ${ }^{71}$ and in humans ${ }^{72}$ and mice ${ }^{73,74}$ with obesity. For example, obese rats (but not lean rats) had downregulated D2 receptors, and their consumption of palatable food was resistant to disruption by an aversive or punishing condition stimulus. ${ }^{75}$ The same study also found that lentivirus-mediated knockdown of striatal D2 receptors accelerated the development of addiction-like reward deficits and the onset of compulsive-like food seeking in rats with access to palatable food, ${ }^{76}$ which is suggestive of reward hyposensitivity. Several recent studies have examined this marker among disordered gamblers. ${ }^{69,77,78}$ While no significant between-group differences in D2/D3 receptor availability at resting state was observed, among disordered gamblers dopamine receptor availability was negatively correlated with mood-related impulsivity ("urgency") within the striatum ${ }^{77}$ and positively correlated with problem-gambling severity within the dorsal striatum. ${ }^{78}$ The precise role for dopamine in gambling disorder continues to be debated, ${ }^{79}$ but a model based on studies in rats and humans suggests different roles for D2, D3, and D4 dopamine receptors, with D3 receptors in the substantia nigra correlating with problem-gambling severity and impulsivity, and linked to greater dopamine release in the dorsal striatum. ${ }^{78,80-82}$

Dopamine receptor agonist medications have been associated with disordered gambling and other behavioral addictions in patients with Parkinson's disease. ${ }^{83-85}$ However, other factors (including age at Parkinson's onset, marital status, and geographic location) independently contribute to the associations between behavioral addictions and Parkinson's disease, suggesting multiple etiologically contributing domains. ${ }^{83}$ Furthermore, drugs with dopamine antagonist properties have not demonstrated efficacy in the treatment of disordered gambling. ${ }^{86,87}$ These findings, in conjunction with those showing the induction of gambling urges by drugs promoting and blocking D2-like dopamine receptor activity, ${ }^{88,89}$ have raised questions regarding the centrality of dopamine to disordered gambling. ${ }^{79}$ Nonetheless, 
recent data suggest that dissecting the inputs from D2, D3, and D4 receptors might elucidate dopamine's role in the pathophysiology of disordered gambling. ${ }^{80,82}$

Evidence exists for serotonergic involvement in behavioral addictions. Serotonin is implicated in emotions, motivation, decision making, behavioral control, and inhibition of behavior. Dysregulated serotonin functioning may mediate behavioral inhibition and impulsivity in disordered gambling. ${ }^{8,67,69}$ Disordered gambling has been associated with reduced levels of the serotonin metabolite 5-hydroxyindoleacetic acid (5-HIAA) in cerebrospinal fluid. ${ }^{90}$ Low levels of platelet monoamine oxidase (MAO) activity (considered a peripheral marker of serotonin activity) among males with disordered gambling 91,92 has provided additional support for serotonergic dysfunction. Striatal binding of a ligand with high affinity for the serotonin $1 \mathrm{~B}$ receptor correlated with problemgambling severity among individuals with disordered gambling. ${ }^{93}$ These findings are consistent with those from challenge studies using meta-chlorophenylpiperazine (m-CPP), a partial agonist with high affinity for the serotonin 1B receptor. These studies observe different biological and behavioral responses in individuals with behavioral or substance addictions (compared to those without) in response to m-CPP. ${ }^{47}$

Less is known about the integrity of other neurotransmitter systems in behavioral addictions. A dysregulated hypothalamic-pituitary-adrenal axis and increased levels of noradrenergic moieties have been observed in disordered gambling. ${ }^{94}$ Noradrenaline may be involved in the peripheral arousal associated with gambling. ${ }^{95,96}$ Opioid antagonists (e.g., naltrexone, nalmefene) have demonstrated superiority over placebo in multiple randomized clinical trials. $^{41,97,98}$

\section{Neural systems}

Neuroimaging studies suggest shared neurocircuitry (particularly involving frontal and striatal regions) between behavioral and substance addictions. Studies using rewardprocessing and decision-making tasks have identified important contributions from subcortical (e.g., striatum) and frontal cortical areas, particularly the ventromedial prefrontal cortex (vmPFC). Among disordered gamblers, versus healthy controls, both decreased ${ }^{99-102}$ and increased vmPFC activity ${ }^{103}$ has been reported during simulated gambling and decisionmaking tasks. Similarly, gambling stimuli has been reported to be associated with both decreased ${ }^{104}$ and increased ${ }^{105,106}$ vmPFC activity in disordered gamblers. The findings from these studies may have been influenced by the specific tasks used, the populations studied, or other factors. ${ }^{99,107,108}$ Relatively greater activation of other frontal and basal ganglia areas, including the amygdala, during high-risk gambling decision making in the Iowa Gambling Task has been observed among disordered gamblers. ${ }^{103}$ While data are relatively limited for other behavior addictions, several recent cue-induction studies have demonstrated activation of brain regions associated with drug-cue exposure. Individuals playing World of Warcraft (a massive, multiplayer, online role-playing game) more than 30 hours per week, compared to nonheavy players (playing less than 2 hours per day) displayed significantly greater orbitofrontal, dorsolateral prefrontal, anterior cingulate, and nucleus accumbens activation when exposed to game cues. ${ }^{109}$ In a separate study, activation in the 
medial orbitofrontal cortex, anterior cingulate, and amygdala in response to anticipated receipt of food was positively correlated with food addiction scores. ${ }^{110}$

As mentioned previously, the mesolimbic pathway (frequently referred to as the "reward pathway") from the ventral tegmental area to the nucleus accumbens has been implicated in both substance and behavioral addictions. ${ }^{111,112}$ Relatively decreased ventral striatal activation has been reported in disordered gamblers during monetary reward anticipation ${ }^{99,100}$ and simulated gambling. ${ }^{101}$ In gambling cue-exposure tasks, disordered gamblers exhibited decreased activation in the ventral ${ }^{113}$ and dorsal ${ }^{114}$ striatum compared to healthy controls. Moreover, both ventral striatal and vmPFC activity was inversely correlated with problem-gambling severity in problem-gambling subjects during simulated gambling. ${ }^{101}$ In seeming contrast to these findings in disordered gambling, a recent functional magnetic resonance imaging study found stronger nucleus accumbens activity among compulsive shoppers (versus controls) during the initial product presentation phase of a multiphase purchasing task. ${ }^{115}$

Unlike findings from patients with SUDs, ${ }^{116}$ studies involving small samples of disordered gamblers did not display significant volumetric differences in white or gray matter from controls, ${ }^{117,118}$ suggesting that volumetric differences observed in SUDs may represent possible neurotoxic sequelae of chronic drug use. More recent data using larger samples, however, show smaller amygdalar and hippocampal volumes in individuals with disordered gambling, similar to findings in SUDs. ${ }^{119}$ Diffusion tensor imaging findings suggest reduced fractional anisotropy values—indicating reduced white matter integrity—in regions including the corpus callosum in disordered gamblers versus controls. ${ }^{118,120}$ Research has demonstrated both widespread reduction of fractional anisotropy in major white-matter pathways and abnormal white-matter structure in Internet addiction. ${ }^{121}$ However, negative results have also been observed for Internet addiction ${ }^{122}$ and hypersexual disorder. ${ }^{123}$

\section{Genetics and Family History}

Twin studies suggest that genetic factors may contribute more than environmental factors to the overall variance of risk for developing disordered gambling. ${ }^{124,125}$ Data from the allmale Vietnam Era Twin Registry estimate the heritability of disordered gambling to be $50 \%-60 \%,{ }^{126,127}$ a statistic comparable to the percentages for substance addictions. ${ }^{128} \mathrm{~A}$ follow-up study of female twins estimated that the proportion of variability in liability for disordered gambling was similar in women and men. ${ }^{124,129}$ Small family studies of probands with disordered gambling, ${ }^{130}$ hypersexual disorder, ${ }^{131}$ and compulsive shopping behavior ${ }^{132}$ have found that first-degree relatives of the probands had significantly higher lifetime rates of SUDs, depression, and other psychiatric disorders, suggesting genetic relationships among these conditions.

Few molecular genetic studies of behavioral addictions have been conducted. Genetic polymorphisms putatively related to dopamine transmission (e.g., DRD2 Taq1A1, which is in linkage disequilibrium with Ankkl) have been associated with disordered gambling 133,134 and problematic video-game playing. ${ }^{135}$ Other research implicates allelic variant in serotonin transmission genes (e.g., 5HTTLPR and MAO-A) in disordered gambling 92,136 and Internet addiction disorder. ${ }^{137}$ These studies, however, typically involved relatively 
small samples and did not account for potential confounds (e.g., those relating to racial and ethnic differences between groups). A recent genome-wide association study reported that no single nucleotide polymorphism reached genome-wide significance for disordered gambling. ${ }^{138}$ Further research is needed to investigate genes and gene-environment interactions that relate to behavioral addictions, with intermediate phenotypes like impulsivity perhaps representing important targets. ${ }^{45,128}$

\section{Addiction Versus Addictions}

The current literature indicates many overlaps between behavioral and substance-related addictions in the domains mentioned above, suggesting that the two sets of disorders may represent different expressions of one "addiction" entity. Nonetheless, differences are also apparent. Although the concept of behavioral addiction appears to be increasingly prominent in the literature, the scientific and empirical evidence remains insufficient for these disorders to be treated as part of one comprehensive, homogenous group. The gaps in our knowledge need to be addressed in order to determine whether behavioral and substance-related addictions represent two different addictions or whether they are different expressions of a core addiction syndrome. Furthermore, separate diagnoses can be clinically useful since individuals may present to practitioners with concerns in specific addiction domains. Nonetheless, the overlaps between the disorders suggest that specific treatments for SUDs may also be beneficial for behavioral addictions.

\section{TREATMENTS}

Treatments for addiction may be divided into three phases. First, a detoxification phase aims to achieve sustained abstinence in a safe manner that reduces immediate withdrawal symptoms (e.g., anxiety, irritability, and emotional instability, which may be present in both behavioral and substance addictions). This first phase may involve medications to assist the transition. The second phase is one of recovery, with emphasis on developing sustained motivation to avoid relapse, learning strategies to cope with cravings, and developing new, healthy patterns of behavior to replace addictive behavior. This phase may involve medications and behavioral treatments. Third, relapse prevention aims to sustain abstinence in the long term. This last phase is perhaps the most difficult to achieve, with waning motivation, the revival of associated learning cues linking hedonic experience to addictive behavior, and temptations that may threaten the recovery process, originating from external (e.g., people, places) and internal (e.g., resumed engagement, stress, interpersonal conflict, symptoms of comorbid mental conditions) cues. Most clinical trials for behavioral addictions have focused on short-term outcomes.

\section{Psychopharmacological Interventions}

No medication has received regulatory approval in the United States as a treatment for disordered gambling. However, multiple double-blind, placebo-controlled trials of various pharmacological agents have demonstrated the superiority of active drugs to placebo. ${ }^{41,139}$

At present, the medications with the strongest empirical support are the opioid receptor antagonists (e.g., naltrexone, nalmefene). These medications have been used in the clinical 
management of drug- (particularly opiate-) and alcohol-dependent patients for several decades ${ }^{140,141}$ and have more recently been evaluated for treating disordered gambling and other behavioral addictions. One double-blind study suggested the efficacy of naltrexone in reducing the intensity of urges to gamble, gambling thoughts, and gambling behavior; in particular, individuals reporting higher intensity of gambling urges responded preferentially to treatment. ${ }^{97}$ These findings have been replicated in larger, longer studies, ${ }^{142}$ and maintenance of positive effects may persist after naltrexone discontinuation. ${ }^{143}$ Medication dosage may be an important consideration in achieving improvement. High doses (100-200 $\mathrm{mg}$ /day) of naltrexone successfully reduced symtpoms of hypersexual disorder and compulsive shopping disorder; ${ }^{144-146}$ they recurred, however, following discontinuation. ${ }^{144}$ In two large, multicenter trials using double-blind, placebo-controlled designs, only the higher doses of nalmefene ( $40 \mathrm{mg} /$ day) showing statistically significant differences from placebo in treatment outcome for disordered gambling. ${ }^{98,147}$ Other data suggest, however, that lower doses (e.g., $50 \mathrm{mg}$ of naltrexone) are sufficient and associated with fewer adverse effects. ${ }^{142,147}$ Importantly, intensity of pretreatment gambling urges and a familial history of alcoholism have been linked to opioid antagonist treatment outcomes in disordered gambling (with stronger urges at treatment onset and a positive family history of alcoholism each associated with better treatment outcome to naltrexone or nalmefene), suggesting important individual differences with respect to treatment response. ${ }^{148}$ The extent to which treatment response might link to specific genetic factors-as has been suggested for alcohol treatment response to naltrexone ${ }^{149}$ —warrants additional study.

With respect to food, preclinical research suggested that high doses of the opiate antagonist naloxone increased sugar consumption and opiate-like withdrawal symptoms-including elevated plus maze anxiety, teeth chattering, and head shakes - in sugar-binging rats following a period of abstinence. ${ }^{150-152}$ These results were not replicated among rats on high-fat diets. ${ }^{153}$ The efficacy of opioid antagonists like naltrexone in treating food addiction has yet to be explored in human subjects but merits research attention.

Although selective serotonin reuptake inhibitors (SSRIs) were one of the first medications that were used to treat disordered gambling, controlled clinical trials assessing SSRIs have demonstrated mixed results for both behavioral and substance addictions. ${ }^{49}$ Fluvoxamine and paroxetine were reported to be superior to placebo in several trials ${ }^{154,155}$ but not in others. ${ }^{156,157}$ Efficacy may differ among behavioral addictions. Citalopram, another SSRI, was found effective in reducing hypersexual disorder symptoms among homosexual and bisexual men ${ }^{158}$ but, among individuals with Internet addiction disorder, did not reduce the number of hours spent online or improve global functioning. ${ }^{159}$ SSRI treatments remain an active area of investigation, ${ }^{8,41}$ and further research is needed to assess the potential clinical utilization of SSRIs for disordered gambling and other behavioral addictions.

Glutamatergic treatments have shown mixed promise in small controlled trials. N-acetyl cysteine has shown preliminary efficacy both as a stand-alone agent ${ }^{160}$ and in conjunction with behavioral treatment. ${ }^{161}$ Topiramate, however, did not show any differences to placebo in treating disordered gambling. ${ }^{162}$ Additionally, the results from these and most other pharmacotherapy trials of behavioral addictions are limited because of the trials' small sample sizes and short-term treatment durations. 


\section{Behavioral Treatments}

Meta-analyses of psychotherapeutic and behavioral treatment approaches for disordered gambling suggest that they can result in significant improvements. Positive effects can be retained (though to a lesser degree) over follow-ups of up to two years. ${ }^{163}$

One approach that has gained empirical support from randomized trials is cognitive behavioral therapy (CBT). This semistructured, problem-oriented approach focuses, in part, on challenging the irrational thought processes and beliefs that are thought to maintain compulsive behaviors. During therapy, patients learn and then implement skills and strategies to change those patterns and interrupt addictive behaviors. ${ }^{164,165}$ Therapists facilitate the replacement of dysfunctional emotions, behaviors, and cognitive processes through engagement in alternative behaviors and a series of goal-orientated, explicit, systematic procedures. CBT is multifaceted but typically involves keeping a diary of significant events and associated feelings, thoughts, and behaviors; recording cognitions, assumptions, evaluations, and beliefs that may be maladaptive; trying new ways of behaving and reacting (e.g., replacing video-game playing with outdoor activities); and, in the cases of disordered gambling and compulsive shopping, learning techniques to properly manage finances. ${ }^{166}$ Such factors are important for initial abstinence but are also essential for relapse prevention. The particular therapeutic techniques that are employed may vary according to the particular type of patient or issue. For example, patients who are having trouble controlling cravings may utilize modules that teach coping strategies specifically for managing cravings. CBT approaches have the strongest evidence base of any of the psychotherapeutic approaches, ${ }^{167}$ with a meta-analysis of randomized, controlled trials demonstrating improvement in gambling-related variables after treatment and at follow-ups in problem gamblers. ${ }^{163}$ In individuals with Internet addiction, CBT has demonstrated efficacy in reducing time spent online, improving social relationships, increasing engagement in offline activities, and increasing the ability to abstain from problematic Internet use. 168

In addition to psychotherapeutic treatments such as CBT, self-help options are available. Although such options have been found to be beneficial for a range of individuals, they may be especially attractive to those people who do not meet diagnostic criteria for disordered gambling and who find psychotherapeutic intervention too costly or intensive. ${ }^{169} \mathrm{~A}$ recent study suggests that Internet-based programs may help reduce disordered gambling symptoms, including at a three-year follow-up. ${ }^{170}$ A popular self-help group based on mutual support is Gambler's Anonymous (GA). Based on the 12-step model of Alcoholics Anonymous, GA stresses commitment to abstinence, which is facilitated by a support network of more experienced group members ("sponsors"). The steps involve admitting loss of control over gambling behavior; recognizing a higher power that can give strength; examining past errors (with the help of a sponsor or experienced member) and making amends; learning to live a new life with a new code of behavior; and helping and carrying the message to other problem gamblers. ${ }^{171}$ Interestingly, individuals with (vs. without) a history of GA attendance were more likely to display higher disordered gambling severity, more years of gambling problems, and larger debts at intake to (other) treatment. ${ }^{172} \mathrm{GA}$ has been shown to have beneficial effects for attendees with varying degrees of gambling 
severity; ${ }^{173}$ however, attrition rates are often high. ${ }^{174}$ The benefits of GA may be increased with adjunctive personalized therapy, and these two approaches, when combined, may be mutually beneficial in promoting continuation of treatment. ${ }^{175}$ Meta-analyses indicate other self-help interventions (e.g., self-help workbooks and audiotapes) also demonstrate beneficial effects in disordered gambling and are superior to no treatment or placebo. The positive effects, however, are typically not as strong as those of other empirically tested psychotherapeutic approaches. ${ }^{163}$

Brief motivational interviewing or enhancement-even as little as a 15-minute telephone consultation - has not only been demonstrated to be effective but in several studies has been shown to be more effective than other lengthier and more intensive approaches. ${ }^{176}$

Motivational interventions center on exploring and resolving a patients' ambivalence toward change, with the aim of facilitating intrinsic motivation and self-efficacy through dealing with problem behaviors. Such interventions could provide a cost-effective, resourceconserving approach and could be particularly useful in individuals reluctant to engage in prolonged therapy on account of stigma, shame, or financial concerns.

Although the precise neural mechanisms mediating the effects of behavioral and pharmacological treatments are unclear, an improved understanding of them could provide insight into the mechanisms underlying specific therapies and assist in treatment development and in matching treatments and individuals. Many promising facets of treatment have yet to be examined in the context of behavioral addictions. For example, positive family involvement has been shown to be beneficial in the treatment of SUDs ${ }^{177}$ and may be similarly helpful in treating behavioral addictions. Additionally, phenotypic heterogeneity exists within each behavioral addiction, and identifying clinically relevant subgroups remains an important endeavor. Testing specific, well-defined behavioral therapies in randomized, controlled trials is also important in validating treatment approaches. Neurocircuitry relating to specific behavioral therapies has been proposed. ${ }^{178}$ The incorporation of pre- and posttreatment neuroimaging assessments into clinical trials represents an important next step for testing these hypotheses.

\section{Combined Approaches}

While much progress has been made in identifying and developing effective pharmacological and behavioral therapies, no existing treatment is completely effective on its own. Combining complementary treatments may help to address weaknesses in either therapy and may thereby catalyze beneficial treatment outcomes. Initial trials using combined approaches have yielded mixed results, with some positive results reported for disordered gambling. ${ }^{161}$

\section{Natural Recovery}

Repeated failed attempts to control gambling constitute a diagnostic feature of disordered gambling, which has typically been taken to imply that gambling disorder may be chronic and associated with multiple relapses. New data are challenging this notion, however, as they indicate variability in the trajectories of gambling problems, indicating a more transient, episodic pattern. ${ }^{1,12,179}$ Formal treatment is uncommon (less than 10\%) of 
individuals who meet criteria for disordered gambling seek formal treatment), ${ }^{180,181}$ the reasons cited for not seeking treatment include denial, shame, and the desire to handle the problem independently. ${ }^{182}$ Very little longitudinal research is available on the natural course of disordered gambling, and still less for other behavioral addictions. Some evidence suggests that young adults frequently move in and out of gambling problems. ${ }^{183}$ Although few direct, long-term studies of gambling relapse have been conducted, it is reasonable to hypothesize that treatment may be essential for sustained abstinence.

\section{Prevention Strategies}

Prevention interventions are important in curbing addictive behaviors. The cost to society of such behaviors could be reduced by introducing and implementing effective educational campaigns that promote community awareness about these behaviors' potentially deleterious health effects and that alert the medical community to the importance of evaluating and treating behavioral addictions. Policies should promote responsible engagement in these behaviors and improve treatment access. Given the high prevalence of behavioral addictions among youth, ${ }^{184}$ school-based prevention programs may be especially beneficial.

\section{OTHER CONSIDERATIONS}

Addictions vary. Social acceptability, a substance's availability, and a behavior's pervasiveness may represent important considerations for treatment. Each behavioral addiction may represent a heterogeneous construct, with specific subtypes potentially relating differently to psychological processes. Different forms of gambling (e.g., strategic versus nonstrategic, sports betting) and different locations (e.g., casino) may present different risks for developing disordered gambling. ${ }^{185,186}$ Similarly, different genres of game playing (e.g., massive, multiplayer online role playing, puzzle and strategy, action), different forms of Internet use (e.g., social networking, email, blogging), and different types of food (e.g., sugar, fat) may possess different addictive potentials and engage cognitive, behavioral, and affective systems in distinct manners. Such differences are important to consider, and warrant further research.

\section{CONCLUDING REMARKS}

Despite significant advances in research, behavioral addictions remain poorly understood.

Our understanding of efficacious, well-tolerated pharmacological and behavioral strategies for behavioral addictions lags significantly behind our understanding of treatments for other major neuropsychiatric disorders. Given the health burden and social impact of these behavioral conditions (e.g., the estimated lifetime cost of disordered gambling in the United States is $\$ 53.8$ billion), ${ }^{187}$ the development and improvement of prevention and treatment strategies are important. The development of health screens and formal diagnostic instruments to assess a full range of behavioral addictions may help reduce the public health burden of these conditions. Additional study in clinical trials of pharmacological and behavioral therapies for behavioral addictions is needed. Continued research may also help identify novel targets for treatment and may assist in identifying relevant individual differences that may be used to guide the selection of therapies. Despite differences, the overlaps between behavioral and substance addictions suggest that comprehensive research 
on the latter may inform an understanding of the former. Through targeted research efforts based on substance addiction findings, the etiology, treatment, and prevention and policy efforts relating to behavioral addictions will potentially move forward rapidly—reducing, in turn, the public health costs and human impact of these conditions.

\section{Acknowledgments}

Supported, in part, by National Institute on Drug Abuse grant nos. P20 DA027844, R01 DA018647, R01 DA035058, and P50 DA09241, National Center for Responsible Gaming, Connecticut State Department of Mental Health and Addictions Services, and Connecticut Mental Health Center (all Dr. Potenza).

\section{References}

1. Potenza MN. Should addictive disorders include non-substance-related conditions? Addiction. 2006; 101:142-51. [PubMed: 16930171]

2. Shaffer HJ, LaPlante DA, LaBrie R, Kidman RC, Donato AN, Stanton MV. Toward a syndrome model of addiction: multiple expressions, common etiology. Harv Rev Psychiatry. 2004; 12:36774. [PubMed: 15764471]

3. Wareham JD, Potenza MN. Pathological gambling and substance use disorders. Am J Drug Alcohol Abuse. 2010; 36:242-7. [PubMed: 20575651]

4. Maddux JF, Desmond DP. Addiction or dependence? Addiction. 2000; 95:661-5. [PubMed: 10885040]

5. Frascella J, Potenza MN, Brown LL, Childress AR. Shared brain vulnerabilities open the way for nonsubstance addictions: carving addiction at a new joint? Ann N Y Acad Sci. 2010; 1187:294-315. [PubMed: 20201859]

6. Karim R, Chaudhri P. Behavioral addictions: an overview. J Psychoactive Drugs. 2012; 44:5-17. [PubMed: 22641961]

7. Holden C. Behavioral addictions debut in proposed DSM-V. Science. 2010; 327:935. [PubMed: 20167757]

8. Brewer JA, Potenza MN. The neurobiology and genetics of impulse control disorders: relationships to drug addictions. Biochem Pharmacol. 2008; 75:63-75. [PubMed: 17719013]

9. Grant JE, Schreiber L, Odlaug BL. Phenomenology and treatment of behavioural addictions. Can J Psychiatry. 2013; 58:252-59. [PubMed: 23756285]

10. Leeman RF, Potenza MN. A targeted review of the neurobiology and genetics of behavioral addictions: an emerging area of research. Can J Psychiatry. 2013; 58:260-73. [PubMed: 23756286]

11. Chambers RA, Taylor JR, Potenza MN. Developmental neurocircuitry of motivation in adolescence: a critical period of addiction vulnerability. Am J Psychiatry. 2003; 160:1041. [PubMed: 12777258]

12. Slutske WS. Natural recovery and treatment-seeking in pathological gambling: results of two national surveys. Am J Psychiatry. 2006; 163:297-302. [PubMed: 16449485]

13. Shaw MC, Forbush KT, Schlinder J, Rosenman E, Black DW. The effect of pathological gambling on families, marriages, and children. CNS Spectr. 2007; 12:615-22. [PubMed: 17667890]

14. Weiser EB. The functions of Internet use and their social and psychological consequences. CyberPsychol Behav. 2001; 4:723-43. [PubMed: 11800180]

15. Lejoyeux M, Weinstein A. Compulsive buying. Am J Drug Alcohol Abuse. 2010; 36:248-53. [PubMed: 20560822]

16. Messerlian C, Derevensky JL. Youth gambling: a public health perspective. J Gambl Issues. 2005; 14:97-116.

17. Wang J, Xiao JJ. Buying behavior, social support and credit card indebtedness of college students. Int J Consum Stud. 2009; 33:2-10.

18. Hollander E, Buchalter AJ, DeCaria CM. Pathological gambling. Psychiatr Clin North Am. 2000; 23:629-42. [PubMed: 10986732] 
19. American Psychiatric Association. Diagnostic and statistical manual of mental disorders. 5. Washington, DC: American Psychiatric Publishing; 2013.

20. Potenza MN. Non-substance addictive behaviors in the context of DSM-5. Addict Behav. 2014; 39:1-2. [PubMed: 24119712]

21. Lesieur HR, Blume SB. The South Oaks Gambling Screen (SOGS): a new instrument for the identification of pathological gamblers. Am J Psychiatry. 1987; 144:1184-8. [PubMed: 3631315]

22. Shaffer HJ, Hall MN, Vander Bilt J. Estimating the prevalence of disordered gambling behavior in the United States and Canada: a research synthesis. Am J Public Health. 1999; 89:1369-76. [PubMed: 10474555]

23. Petry NM, Stinson FS, Grant BF. Comorbidity of DSM-IV pathological gambling and other psychiatric disorders: results from the National Epidemiologic Survey on Alcohol and Related Conditions. J Clin Psychiatry. 2005; 66:564-74. [PubMed: 15889941]

24. Lorains FK, Cowlishaw S, Thomas SA. Prevalence of comorbid disorders in problem and pathological gambling: systematic review and meta-analysis of population surveys. Addiction. 2011; 106:490-8. [PubMed: 21210880]

25. Blinn-Pike L, Worthy SL, Jonkman JN. Disordered gambling among college students: a metaanalytic synthesis. J Gambl Stud. 2007; 23:175-83. [PubMed: 17160587]

26. Gentile DA, Choo H, Liau A, et al. Pathological video game use among youths: a two-year longitudinal study. Pediatrics. 2011; 127:e319-29. [PubMed: 21242221]

27. Ko CH, Yen JY, Chen SH, Yang MJ, Lin HC, Yen CF. Proposed diagnostic criteria and the screening and diagnostic tool of Internet addiction in college students. Compr Psychiatry. 2009; 50:378-84. [PubMed: 19486737]

28. Young, KS. Internet addiction: symptoms, evaluation and treatment. In: VandeCreek, L.; Jackson, T., editors. Innovations in clinical practice: a source book. Sarasota, FL: Professional Resource; 1999. p. 19-31.

29. Yau YHC, Crowley MJ, Mayes LC, Potenza MN. Are Internet use and video-game-playing addictive behaviors? Biological, clinical and public health implications for youths and adults. Minerva Psichiatr. 2012; 53:153-70. [PubMed: 24288435]

30. Kessler RC, Hwang I, LaBrie R, et al. DSM-IV pathological gambling in the National Comorbidity Survey Replication. Psychol Med. 2008; 38:1351-60. [PubMed: 18257941]

31. el-Guebaly N, Mudry T, Zohar J, Tavares H, Potenza MN. Compulsive features in behavioural addictions: the case of pathological gambling. Addiction. 2012; 107:1726-34. [PubMed: 21985690]

32. Bland RC, Newman SC, Orn H, Stebelsky G. Epidemiology of pathological gambling in Edmonton. Can J Psychiatry. 1993; 38:108-12. [PubMed: 8467435]

33. Yau, Y.; Yip, S.; Potenza, MN. Understanding "behavioral addictions:" insights from research. In: Fiellin, DA.; Miller, SC.; Saitz, R., editors. The ASAM principles of addiction medicine. 5. Philadelphia: Wolters Kluwer; 2014.

34. Yen J-Y, Ko C-H, Yen C-F, Chen C-S, Chen C-C. The association between harmful alcohol use and Internet addiction among college students: comparison of personality. Psychiatr Clin Neurosci. 2009; 63:218-24.

35. Mazhari S. Association between problematic internet use and impulse control disorders among Iranian university students. Cyberpsychol Behav Soc Netw. 2012; 15:270-3. [PubMed: 22489545]

36. Dowling NA, Brown M. Commonalities in the psychological factors associated with problem gambling and Internet dependence. Cyberpsychol Behav Soc. 2010; 13:437-41.

37. Blaszczynski A, Nower L. A pathways model of problem and pathological gambling. Addiction. 2002; 97:487-99. [PubMed: 12033650]

38. Chou KL, Afifi TO. Disordered (pathologic or problem) gambling and axis I psychiatric disorders: results from the National Epidemiologic Survey on Alcohol and Related Conditions. Am J Epidemiol. 2011; 173:1289-97. [PubMed: 21467151]

39. Pilver CE, Libby DJ, Hoff RA, Potenza MN. Gender differences in the relationship between gambling problems and the incidence of substance-use disorders in a nationally representative population sample. Drug Alcohol Depend. 2013; 133:204-11. [PubMed: 23755930] 
40. Pilver CE, Potenza MN. Increased incidence of cardiovascular conditions among older adults with pathological gambling features in a prospective study. J Addict Med. 2013; 7:387-93. [PubMed: 24104190]

41. Bullock SA, Potenza MN. Pathological gambling: neuropsychopharmacology and treatment. Curr Psychopharmacol. 2012; 1:67-85.

42. Chambers RA, Bickel WK, Potenza MN. A scale-free systems theory of motivation and addiction. Neurosci Biobehav Rev. 2007; 31:1017-45. [PubMed: 17574673]

43. Redish AD, Jensen S, Johnson A. A unified framework for addiction: vulnerabilities in the decision process. Behav Brain Sci. 2008; 31:415-37. [PubMed: 18662461]

44. Goldstein RZ, Alia-Klein N, Tomasi D, et al. Is decreased prefrontal cortical sensitivity to monetary reward associated with impaired motivation and self-control in cocaine addiction? Am $\mathrm{J}$ Psychiatry. 2007; 164:43-51. [PubMed: 17202543]

45. Fineberg NA, Chamberlain SR, Goudriaan AE, et al. New developments in human neurocognition: clinical, genetic, and brain imaging correlates of impulsivity and compulsivity. CNS Spectr. 2014; 19:69-89. [PubMed: 24512640]

46. Verdejo-Garcia A, Lawrence AJ, Clark L. Impulsivity as a vulnerability marker for substance-use disorders: review of findings from high-risk research, problem gamblers and genetic association studies. Neurosci Biobehav Rev. 2008; 32:777-810. [PubMed: 18295884]

47. Leeman RF, Potenza MN. Similarities and differences between pathological gambling and substance use disorders: a focus on impulsivity and compulsivity. Psychopharmacology. 2012; 219:469-90. [PubMed: 22057662]

48. Tavares H, Zilberman ML, Hodgins DC, El-Guebaly N. Comparison of craving between pathological gamblers and alcoholics. Alcohol Clin Exp Res. 2005; 29:1427-31. [PubMed: 16131850]

49. Potenza MN, Koran LM, Pallanti S. The relationship between impulse-control disorders and obsessive-compulsive disorder: a current understanding and future research directions. Psychiatr Res. 2009; 170:22-31.

50. Hollander E, Wong CM. Obsessive-compulsive spectrum disorders. J Clin Psychiatry. 1995; 56 (suppl 4):3-6. discussion 53-5. [PubMed: 7713863]

51. Fineberg NA, Potenza MN, Chamberlain SR, et al. Probing compulsive and impulsive behaviors, from animal models to endophenotypes: a narrative review. Neuropsychopharmacology. 2010; 35:591-604. [PubMed: 19940844]

52. Odlaug BL, Chamberlain SR, Grant JE. Motor inhibition and cognitive flexibility in pathologic skin picking. Prog Neuropsychopharmacol Biol Psychiatry. 2010; 34:208-11. [PubMed: 19913592]

53. Sumnall HR, Wagstaff GF, Cole JC. Self-reported psychopathology in polydrug users. J Psychopharmacol. 2004; 18:75-82. [PubMed: 15107188]

54. Odlaug BL, Chamberlain SR, Kim SW, Schreiber LRN, Grant JE. A neurocognitive comparison of cognitive flexibility and response inhibition in gamblers with varying degrees of clinical severity. Psychol Med. 2011; 41:2111-9. [PubMed: 21426627]

55. Goudriaan AE, Oosterlaan J, De Beurs E, Van den Brink W. The role of self-reported impulsivity and reward sensitivity versus neurocognitive measures of disinhibition and decision-making in the prediction of relapse in pathological gamblers. Psychol Med. 2008; 38:41-50. [PubMed: 17498322]

56. Lawrence A, Luty J, Bogdan N, Sahakian B, Clark L. Problem gamblers share deficits in impulsive decision-making with alcohol-dependent individuals. Addiction. 2009; 104:1006-15. [PubMed: 19466924]

57. Goudriaan AE, Oosterlaan J, de Beurs E, van den Brink W. Decision making in pathological gambling: a comparison between pathological gamblers, alcohol dependents, persons with Tourette syndrome, and normal controls. Brain Res Cogn Brain Res. 2005; 23:137-51. [PubMed: 15795140]

58. Ko CH, Hsiao S, Liu GC, Yen JY, Yang MJ, Yen CF. The characteristics of decision making, potential to take risks, and personality of college students with Internet addiction. Psychiatry Res. 2010; 175:121-5. [PubMed: 19962767] 
59. Everitt BJ, Robbins TW. Neural systems of reinforcement for drug addiction: from actions to habits to compulsion. Nat Neurosci. 2005; 8:1481-9. [PubMed: 16251991]

60. Reynolds B. A review of delay-discounting research with humans: relations to drug use and gambling. Behav Pharmacol. 2006; 17:651-67. [PubMed: 17110792]

61. Mitchell MR, MNP. Addictions and personality traits: impulsivity and related constructs. Curr Behav Neurosci Rep. 2014; 1:1-12. [PubMed: 24772382]

62. Petry NM. Discounting of probabilistic rewards is associated with gambling abstinence in treatment-seeking pathological gamblers. J Abnorm Psychol. 2012; 121:151-9. [PubMed: 21842965]

63. Koob GF, Volkow ND. Neurocircuitry of addiction. Neuropsychopharmacology. 2010; 35:217-38. [PubMed: 19710631]

64. Weinstein AM. Computer and video game addiction-a comparison between game users and nongame users. Am J Drug Alcohol Abuse. 2010; 36:268-76. [PubMed: 20545602]

65. Farde L, Nordström AL, Wiesel FA, Pauli S, Halldin C, Sedvall G. Positron emission tomographic analysis of central D1 and D2 dopamine receptor occupancy in patients treated with classical neuroleptics and clozapine. Arch Gen Psychiatry. 1992; 49:538-44. [PubMed: 1352677]

66. Volkow ND, Wang GJ, Fowler JS, et al. Imaging endogenous dopamine competition with [11C]raclopride in the human brain. Synapse. 1994; 16:255-62. [PubMed: 8059335]

67. Linnet J, Moller A, Peterson E, Gjedde A, Doudet D. Inverse association between dopaminergic neurotransmission and Iowa Gambling Task performance in pathological gamblers and healthy controls. Scand J Psychol. 2011; 52:28-34. [PubMed: 20704689]

68. Joutsa J, Johansson J, Niemelä S, et al. Mesolimbic dopamine release is linked to symptom severity in pathological gambling. Neuroimage. 2012; 60:1992-9. [PubMed: 22348881]

69. Linnet J, Møller A, Peterson E, Gjedde A, Doudet D. Dopamine release in ventral striatum during Iowa Gambling Task performance is associated with increased excitement levels in pathological gambling. Addiction. 2011; 106:383-90. [PubMed: 20883460]

70. Volkow ND, Chang L, Wang GJ, et al. Low level of brain dopamine D2 receptors in methamphetamine abusers: association with metabolism in the orbitofrontal cortex. Am J Psychiatry. 2001; 158:2015-21. [PubMed: 11729018]

71. Kim SH, Baik S-H, Park CS, Kim SJ, Choi SW, Kim SE. Reduced striatal dopamine D2 receptors in people with Internet addiction. Neuroreport. 2011; 22:407-11. [PubMed: 21499141]

72. Wang GJ, Volkow ND, Thanos PK, Fowler JS. Imaging of brain dopamine pathways: implications for understanding obesity. J Addict Med. 2009; 3:8-18. [PubMed: 21603099]

73. Huang XF, Zavitsanou K, Huang X, et al. Dopamine transporter and D2 receptor binding densities in mice prone or resistant to chronic high fat diet-induced obesity. Behav Brain Res. 2006; 175:415-9. [PubMed: 17000016]

74. Geiger BM, Behr GG, Frank LE, et al. Evidence for defective mesolimbic dopamine exocytosis in obesity-prone rats. FASEB J. 2008; 22:2740-6. [PubMed: 18477764]

75. Johnson PM, Kenny PJ. Dopamine D2 receptors in addiction-like reward dysfunction and compulsive eating in obese rats. Nat Neurosci. 2010; 13:635-41. [PubMed: 20348917]

76. Johnson JA, Lee A, Vinson D, Seale JP. Use of AUDIT-based measures to identify unhealthy alcohol use and alcohol dependence in primary care: a validation study. Alcohol Clin Exp Res. 2013; 37 (suppl 1):E253-9. [PubMed: 22834916]

77. Clark L, Stokes PR, Wu K, et al. Striatal dopamine D2/D3 receptor binding in pathological gambling is correlated with mood-related impulsivity. Neuroimage. 2012; 63:40-6. [PubMed: 22776462]

78. Boileau I, Payer D, Chugani B, et al. The D2/3 dopamine receptor in pathological gambling: a positron emission tomography study with [11C]-(+)-propyl-hexahydro-naphtho-oxazin and [11C]raclopride. Addiction. 2013; 108:953-63. [PubMed: 23167711]

79. Potenza MN. How central is dopamine to pathological gambling or gambling disorder? Front Behav Neurosci. 2013; 7:206. [PubMed: 24391562]

80. Boileau I, Payer D, Chugani B, et al. In vivo evidence for greater amphetamine-induced dopamine release in pathological gambling: a positron emission tomography study with [11C]-(+)-PHNO. Mol Psychiatry. 2014; 19:1305-13. [PubMed: 24322203] 
81. Potenza MN. The neural bases of cognitive processes in gambling disorder. Trends Cogn Sci. 2014; 18:429-38. [PubMed: 24961632]

82. Cocker PJ, Le Foll B, Rogers RD, Winstanley CA. A selective role for dopamine D4 receptors in modulating reward expectancy in a rodent slot machine task. Biol Psychiatry. 2014; 75:817-24. [PubMed: 24094512]

83. Weintraub D, Koester J, Potenza MN, et al. Impulse control disorders in parkinson disease: A cross-sectional study of 3090 patients. Arch Neurol. 2010; 67:589-95. [PubMed: 20457959]

84. Voon V, Sohr M, Lang AE, et al. Impulse control disorders in Parkinson disease: a multicenter case-control study. Ann Neurol. 2011; 69:986-96. [PubMed: 21416496]

85. Leeman RF, Billingsley BE, Potenza MN. Impulse control disorders in Parkinson's Disease: background and update on prevention and management. Neurodegener Dis Manag. 2012; 2:389400. [PubMed: 23606908]

86. McElroy SL, Nelson E, Welge J, Kaehler L, Keck P. Olanzapine in the treatment of pathological gambling: a negative randomized placebo-controlled trial. Journal Clin Psychiatry. 2008; 69:43340 .

87. Fong T, Kalechstein A, Bernhard B, Rosenthal R, Rugle L. A double-blind, placebo-controlled trial of olanzapine for the treatment of video poker pathological gamblers. Pharmacol Biochem Behav. 2008; 89:298-303. [PubMed: 18261787]

88. Zack M, Poulos CX. A D2 antagonist enhances the rewarding and priming effects of a gambling episode in pathological gamblers. Neuropsychopharmacology. 2007; 32:1678-86. [PubMed: 17203013]

89. Zack M, Poulos CX. Amphetamine primes motivation to gamble and gambling-related semantic networks in problem gamblers. Neuropsychopharmacology. 2004; 29:195-207. [PubMed: 14571257]

90. Nordin C, Eklundh T. Altered CSF 5-HIAA disposition in pathological male gamblers. CNS Spectr. 1999; 4:25-33. [PubMed: 18311105]

91. de Castro IP, Ibanez A, Saiz-Ruiz J, Fernandez-Piqueras J. Concurrent positive association between pathological gambling and functional DNA polymorphisms at the MAO-A and the 5-HT transporter genes. Mol Psychiatry. 2002; 7:927-8. [PubMed: 12399942]

92. Ibanez A, Perez de Castro I, Fernandez-Piqueras J, Blanco C, Saiz-Ruiz J. Pathological gambling and DNA polymorphic markers at MAO-A and MAO-B genes. Mol Psychiatry. 2000; 5:105-9. [PubMed: 10673777]

93. Potenza MN, Walderhaug E, Henry S, et al. Serotonin 1B receptor imaging in pathological gambling. World J Biol Psychiatry. 2013; 14:139-45. [PubMed: 21936763]

94. Meyer G, Schwertfeger J, Exton MS, et al. Neuroendocrine response to casino gambling in problem gamblers. Psychoneuroendocrinology. 2004; 29:1272-80. [PubMed: 15288706]

95. Pallanti S, Bernardi S, Allen A, et al. Noradrenergic function in pathological gambling: blunted growth hormone response to clonidine. J Psychopharmacol. 2010; 24:847-53. [PubMed: 19028836]

96. Elman I, Becerra L, Tschibelu E, Yamamoto R, George E, Borsook D. Yohimbine-induced amygdala activation in pathological gamblers: a pilot study. PLoS One. 2012; 7:e31118. [PubMed: 22319607]

97. Kim SW, Grant JE, Adson DE, Shin YC. Double-blind naltrexone and placebo comparison study in the treatment of pathological gambling. Biol Psychiatry. 2001; 49:914-21. [PubMed: 11377409]

98. Grant JE, Odlaug BL, Potenza MN, Hollander E, Kim SW. Nalmefene in the treatment of pathological gambling: multicentre, double-blind, placebo-controlled study. Br J Psychiatry. 2010; 197:330-1. [PubMed: 20884959]

99. Balodis IM, Kober H, Worhunsky PD, Stevens MC, Pearlson GD, Potenza MN. Diminished frontostriatal activity during processing of monetary rewards and losses in pathological gambling. Biol Psychiatry. 2012; 71:749-57. [PubMed: 22336565]

100. Choi J-S, Shin Y-C, Jung WH, et al. Altered brain activity during reward anticipation in pathological gambling and obsessive-compulsive disorder. PLoS One. 2012; 7:e45938. [PubMed: 23029329] 
101. Reuter J, Raedler T, Rose M, Hand I, Glascher J, Buchel C. Pathological gambling is linked to reduced activation of the mesolimbic reward system. Nat Neurosci. 2005; 8:147-8. [PubMed: 15643429]

102. Tanabe J, Thompson L, Claus E, Dalwani M, Hutchison K, Banich MT. Prefrontal cortex activity is reduced in gambling and nongambling substance users during decision-making. Hum Brain Mapp. 2007; 28:1276-86. [PubMed: 17274020]

103. Power Y, Goodyear B, Crockford D. Neural correlates of pathological gamblers preference for immediate rewards during the iowa gambling task: an fMRI study. J Gambl Stud. 2011:1-14. [PubMed: 20514512]

104. Potenza MN, Steinberg MA, Skudlarski P, et al. Gambling urges in pathological gambling: a functional magnetic resonance imaging study. Arch Gen Psychiatry. 2003; 60:828-36. [PubMed: 12912766]

105. Goudriaan AE, De Ruiter MB, Van Den Brink W, Oosterlaan J, Veltman DJ. Brain activation patterns associated with cue reactivity and craving in abstinent problem gamblers, heavy smokers and healthy controls: an fMRI study. Addiction Biol. 2010; 15:491-503.

106. Crockford DN, Goodyear B, Edwards J, Quickfall J, el-Guebaly N. Cue-induced brain activity in pathological gamblers. Biol Psychiatry. 2005; 58:787-95. [PubMed: 15993856]

107. van Holst RJ, Veltman DJ, Büchel C, van den Brink W, Goudriaan AE. Distorted expectancy coding in problem gambling: is the addictive in the anticipation? Biol Psychiatry. 2012; 71:7418. [PubMed: 22342105]

108. Leyton M, Vezina P. On cue: striatal ups and downs in addictions. Biol Psychiatry. 2012; 72:e21e2. [PubMed: 22789688]

109. Ko C-H, Liu G-C, Hsiao S, et al. Brain activities associated with gaming urge of online gaming addiction. J Psychiatr Res. 2009; 43:739-47. [PubMed: 18996542]

110. Gearhardt AN, Yokum S, Orr PT, Stice E, Corbin WR, Brownell KD. Neural correlates of food addiction. Arch Gen Psychiatry. 2011; 68:808-16. [PubMed: 21464344]

111. Wrase J, Schlagenhauf F, Kienast T, et al. Dysfunction of reward processing correlates with alcohol craving in detoxified alcoholics. Neuroimage. 2007; 35:787-94. [PubMed: 17291784]

112. Hommer DW, Bjork JM, Gilman JM. Imaging brain response to reward in addictive disorders. Ann N Y Acad Sci. 2011; 1216:50-61. [PubMed: 21272010]

113. Potenza MN. The neurobiology of pathological gambling and drug addiction: an overview and new findings. Philos Trans R Soc Lond B Biol Sci. 2008; 363:3181-9. [PubMed: 18640909]

114. de Greck M, Enzi B, Prösch U, Gantman A, Tempelmann C, Northoff G. Decreased neuronal activity in reward circuitry of pathological gamblers during processing of personal relevant stimuli. Hum Brain Mapp. 2010; 31:1802-12. [PubMed: 20162606]

115. Raab G, Elger C, Neuner M, Weber B. A neurological study of compulsive buying behaviour. J Consum Policy. 2011; 34:401-13.

116. Ersche KD, Jones PS, Williams GB, Turton AJ, Robbins TW, Bullmore ET. Abnormal brain structure implicated in stimulant drug addiction. Science. 2012; 335:601-4. [PubMed: 22301321]

117. van Holst RJ, de Ruiter MB, van den Brink W, Veltman DJ, Goudriaan AE. A voxel-based morphometry study comparing problem gamblers, alcohol abusers, and healthy controls. Drug Alcohol Depend. 2012; 124:142-8. [PubMed: 22270405]

118. Joutsa J, Saunavaara J, Parkkola R, Niemelä S, Kaasinen V. Extensive abnormality of brain white matter integrity in pathological gambling. Psychiatry Res. 2011; 194:340-6. [PubMed: 22079653]

119. Rahman AS, Xu J, Potenza MN. Hippocampal and amygdalar volumetric differences in pathological gambling: a preliminary study of the associations with the behavioral inhibition system. Neuropsychopharmacology. 2014; 39:738-45. [PubMed: 24077065]

120. Yip SW, Lacadie CM, Xu J, et al. Reduced genual corpus callosal white matter integrity in pathological gambling and its relationship to alcohol abuse or dependence. World J Biol Psychiatry. 2013; 14:129-38. [PubMed: 21545245]

121. Lin F, Zhou Y, Du Y, et al. Abnormal white matter integrity in adolescents with Internet addiction disorder: a tract-based spatial statistics study. PLoS One. 2012; 7:e30253. [PubMed: 22253926] 
122. Yuan K, Qin W, Wang G, et al. Microstructure abnormalities in adolescents with Internet addiction disorder. PLoS One. 2011; 6:e20708. [PubMed: 21677775]

123. Miner MH, Raymond N, Mueller BA, Lloyd M, Lim KO. Preliminary investigation of the impulsive and neuroanatomical characteristics of compulsive sexual behavior. Psychiatry Res. 2009; 174:146-51. [PubMed: 19836930]

124. Slutske WS, Zhu G, Meier MH, Martin NG. Genetic and environmental influences on disordered gambling in men and women. Arch Gen Psychiatry. 2010; 67:624-30. [PubMed: 20530012]

125. Blanco C, Myers J, Kendler KS. Gambling, disordered gambling and their association with major depression and substance use: a Web-based cohort and twin-sibling study. Psychol Med. 2012; 42:497-508. [PubMed: 21835089]

126. Lobo DS, Kennedy JL. Genetic aspects of pathological gambling: a complex disorder with shared genetic vulnerabilities. Addiction. 2009; 104:1454-65. [PubMed: 19686516]

127. Shah KR, Eisen SA, Xian H, Potenza MN. Genetic studies of pathological gambling: a review of methodology and analyses of data from the Vietnam Era Twin Registry. J Gambl Stud. 2005; 21:179-203. [PubMed: 15870986]

128. Kreek MJ, Nielsen DA, Butelman ER, LaForge KS. Genetic influences on impulsivity, risk taking, stress responsivity and vulnerability to drug abuse and addiction. Nat Neurosci. 2005; 8:1450-7. [PubMed: 16251987]

129. Slutske WS, Ellingson JM, Richmond-Rakerd LS, Zhu G, Martin NG. Shared genetic vulnerability for disordered gambling and alcohol use disorder in men and women: evidence from a national community-based Australian twin study. Twin Res Hum Genet. 2013; 16:52534. [PubMed: 23527679]

130. Black DW, Monahan PO, Temkit MH, Shaw M. A family study of pathological gambling. Psychiatry Res. 2006; 141:295-303. [PubMed: 16499975]

131. Schneider JP, Schneider BH. Couple recovery from sexual addiction: research findings of a survey of 88 marriages. Sex Addict Compulsivity. 1996; 3:111-26.

132. McElroy SL, Keck PE Jr, Pope HG Jr, Smith JM, Strakowski SM. Compulsive buying: a report of 20 cases. J Clin Psychiatry. 1994; 55:242-8. [PubMed: 8071278]

133. Comings DE, Rosenthal RJ, Lesieur HR, et al. A study of the dopamine D2 receptor gene in pathological gambling. Pharmacogenetics. 1996; 6:223-34. [PubMed: 8807661]

134. Lobo DSS, Souza RP, Tong RP, et al. Association of functional variants in the dopamine D2-like receptors with risk for gambling behaviour in healthy Caucasian subjects. Biol Psychol. 2010; 85:33-7. [PubMed: 20452395]

135. Han DH, Lee YS, Yang KC, Kim EY, Lyoo IK, Renshaw PF. Dopamine genes and reward dependence in adolescents with excessive internet video game play. J Addict Med. 2007; 1:1338. [PubMed: 21768948]

136. de Castro IP, Ibánez A, Saiz-Ruiz J, Fernández-Piqueras J. Genetic contribution to pathological gambling: possible association between a functional DNA polymorphism at the serotonin transporter gene (5-HTT) and affected men. Pharmacogenet Genomics. 1999; 9:397-400.

137. Lee YS, Han D, Yang KC, et al. Depression like characteristics of 5HTTLPR polymorphism and temperament in excessive internet users. J Affect Disord. 2008; 109:165-9. [PubMed: 18045695]

138. Lind PA, Zhu G, Montgomery GW, et al. Genome-wide association study of a quantitative disordered gambling trait. Addict Biol. 2012; 18:511-22. [PubMed: 22780124]

139. Yip S, Potenza MN. Treatment of gambling disorders. Curr Treat Options Psychiatry. 2014; 1(2): 189-203. [PubMed: 24904757]

140. Krystal JH, Cramer JA, Krol WF, Kirk GF, Rosenheck RA. Naltrexone in the treatment of alcohol dependence. New Engl J Med. 2001; 345:1734-9. [PubMed: 11742047]

141. O'Brien C, Thomas McLellan A. Myths about the treatment of addiction. Lancet. 1996; 347:23740. [PubMed: 8551886]

142. Grant JE, Kim SW, Hartman BK. A double-blind, placebo-controlled study of the opiate antagonist naltrexone in the treatment of pathological gambling urges. J Clin Psychiatry. 2008; 69:783-9. [PubMed: 18384246]

Harv Rev Psychiatry. Author manuscript; available in PMC 2016 March 01. 
143. Dannon PN, Lowengrub K, Musin E, Gonopolsky Y, Kotler M. 12-month follow-up study of drug treatment in pathological gamblers: a primary outcome study. J Clin Psychopharmacol. 2007; 27:620-4. [PubMed: 18004130]

144. Grant J, Kim SW. A case of kleptomania and compulsive sexual behavior treated with naltrexone. Ann Clin Psychiatry. 2001; 13:229-31. [PubMed: 11958364]

145. Raymond NC, Grant JE, Kim SW, Coleman E. Treatment of compulsive sexual behaviour with naltrexone and serotonin reuptake inhibitors: two case studies. Int Clin Psychopharmacol. 2002; 17:201-5. [PubMed: 12131605]

146. Grant JE. Three cases of compulsive buying treated with naltrexone. Int J Psychiatry Clin Pract. 2003; 7:223-5.

147. Grant JE, Potenza MN, Hollander E, et al. Multicenter investigation of the opioid antagonist nalmefene in the treatment of pathological gambling. Am J Psychiatry. 2006; 163:303-12. [PubMed: 16449486]

148. Grant JE, Kim SW, Hollander E, Potenza MN. Predicting response to opiate antagonists and placebo in the treatment of pathological gambling. Psychopharmacology. 2008; 200:521-7. [PubMed: 18581096]

149. Oslin DW, Berrettini W, Kranzler HR, et al. A functional polymorphism of the $\mu$-opioid receptor gene is associated with naltrexone response in alcohol-dependent patients. Neuropsychopharmacology. 2003; 28:1546-52. [PubMed: 12813472]

150. Avena NM, Bocarsly ME, Rada P, Kim A, Hoebel BG. After daily bingeing on a sucrose solution, food deprivation induces anxiety and accumbens dopamine/acetylcholine imbalance. Physiol Behav. 2008; 94:309-15. [PubMed: 18325546]

151. Colantuoni C, Rada P, McCarthy J, et al. Evidence that intermittent, excessive sugar intake causes endogenous opioid dependence. Obes Res. 2002; 10:478-88. [PubMed: 12055324]

152. Avena NM, Rada P, Hoebel BG. Sugar and fat bingeing have notable differences in addictive-like behavior. J Nutr. 2009; 139:623-8. [PubMed: 19176748]

153. Bocarsly ME, Berner LA, Hoebel BG, Avena NM. Rats that binge eat fat-rich food do not show somatic signs or anxiety associated with opiate-like withdrawal: implications for nutrient-specific food addiction behaviors. Physiol Behav. 2011; 104:865-72. [PubMed: 21635910]

154. Hollander E, DeCaria CM, Finkell JN, Begaz T, Wong CM, Cartwright C. A randomized doubleblind fluvoxamine/placebo crossover trial in pathologic gambling. Biol Psychiatry. 2000; 47:813-7. [PubMed: 10812040]

155. Kim SW, Grant JE, Adson DE, Shin YC, Zaninelli R. A double-blind placebo-controlled study of the efficacy and safety of paroxetine in the treatment of pathological gambling. J Clin Psychiatry. 2002; 63:501-7. [PubMed: 12088161]

156. Blanco C, Petkova E, Ibanez A, Saiz-Ruiz J. A pilot placebo-controlled study of fluvoxamine for pathological gambling. Ann Clin Psychiatry. 2002; 14:9-15. [PubMed: 12046642]

157. Grant JE, Kim SW, Potenza MN, et al. Paroxetine treatment of pathological gambling: a multicentre randomized controlled trial. Int Clin Psychopharmacol. 2003; 18:243-9. [PubMed: 12817159]

158. Wainberg ML, Muench F, Morgenstern J, et al. A double-blind study of citalopram versus placebo in the treatment of compulsive sexual behaviors in gay and bisexual men. J Clin Psychiatry. 2006; 67:1968-73. [PubMed: 17194276]

159. Dell'Osso B, Hadley S, Allen A, Baker B, Chaplin WF, Hollander E. Escitalopram in the treatment of impulsive-compulsive internet usage disorder: an open-label trial followed by a double-blind discontinuation phase. J Clin Psychiatry. 2008; 69:452-6. [PubMed: 18312057]

160. Grant JE, Kim SW, Odlaug BL. N-acetyl cysteine, a glutamate-modulating agent, in the treatment of pathological gambling: a pilot study. Biol Psychiatry. 2007; 62:652-7. [PubMed: 17445781]

161. Grant JE, Odlaug BL, Chamberlain SR, et al. A randomized, placebo-controlled trial of Nacetylcysteine plus imaginal desensitization for nicotine-dependent pathological gamblers. J Clin Psychiatry. 2014; 75:39-45. [PubMed: 24345329]

162. Berlin HA, Braun A, Simeon D, et al. A double-blind, placebo-controlled trial of topiramate for pathological gambling. World J Biol Psychiatry. 2013; 14:121-8. [PubMed: 21486110] 
163. Pallesen S, Mitsem M, Kvale G, Johnsen BH, Molde H. Outcome of psychological treatments of pathological gambling: a review and meta-analysis. Addiction. 2005; 100:1412-22. [PubMed: 16185203]

164. Tolin DF. Is cognitive-behavioral therapy more effective than other therapies? : a meta-analytic review. Clin Psychol Rev. 2010; 30:710-20. [PubMed: 20547435]

165. Petry NM, Ammerman Y, Bohl J, et al. Cognitive-behavioral therapy for pathological gamblers. J Consult Clin Psychol. 2006; 74:555-67. [PubMed: 16822112]

166. Petry, NM. Pathological gambling: etiology, comorbidity, and treatment. Washington, DC: American Psychological Association; 2005.

167. Cowlishaw S, Merkouris S, Dowling N, Anderson C, Jackson A, Thomas S. Psychological therapies for pathological and problem gambling. Cochrane Database Syst Rev. 2012; 11:CD008937. [PubMed: 23152266]

168. Young KS. Cognitive behavior therapy with Internet addicts: treatment outcomes and implications. Cyberpsychol Behav. 2007; 10:671-9. [PubMed: 17927535]

169. Raylu N, Oei TP, Loo J. The current status and future direction of self-help treatments for problem gamblers. Clin Psychol Rev. 2008; 28:1372-85. [PubMed: 18760868]

170. Carlbring P, Degerman N, Jonsson J, Andersson G. Internet-based treatment of pathological gambling with a three-year follow-up. Cogn Behav Ther. 2012; 41:321-34. [PubMed: 22620990]

171. Gamblers Anonymous: Recovery Program. 2013. http://www.gamblersanonymous.org/ga/ content/recovery-program

172. Petry NM. Patterns and correlates of Gamblers Anonymous attendance in pathological gamblers seeking professional treatment. Addict Behav. 2003; 28:1049-62. [PubMed: 12834650]

173. Petry NM. Gamblers anonymous and cognitive-behavioral therapies for pathological gamblers. J Gambl Stud. 2005; 21:27-33. [PubMed: 15789187]

174. Brewer JA, Grant JE, Potenza MN. The treatment of pathologic gambling. Addict Disord Their Treat. 2008; 7:1-13.

175. Grant, JE.; Odlaug, BL. National Center for Responsible Gaming. What clinicians need to know about gambling disorders. Vol. 7. Washington, DC: NCRG; 2012. Psychosocial interventions for gambling disorders; p. 38-52.Increasing the odds: a series dedicated to understanding gambling disorders. At http://www.ncrg.org/resources/monographs

176. Hodgins DC, Currie S, el-Guebaly N, Peden N. Brief motivational treatment for problem gambling: a 24-month follow-up. Psychol Addict Behav. 2004; 18:293. [PubMed: 15482086]

177. Copello AG, Velleman RD, Templeton LJ. Family interventions in the treatment of alcohol and drug problems. Drug Alcohol Rev. 2005; 24:369-85. [PubMed: 16234133]

178. Potenza MN, Balodis IM, Franco CA, et al. Neurobiological considerations in understanding behavioral treatments for pathological gambling. Psychol Addictive Behav. 2013; 27:380-92.

179. LaPlante DA, Nelson SE, LaBrie R, Shaffer HJ. Stability and progression of disordered gambling: lessons from longitudinal studies. Can J Psychiatry. 2008; 53:52-60. [PubMed: 18286872]

180. Slutske WS, Blaszczynski A, Martin NG. Sex differences in the rates of recovery, treatmentseeking, and natural recovery in pathological gambling: results from an Australian communitybased twin survey. Twin Res Hum Genet. 2009; 12:425-32. [PubMed: 19803770]

181. Cunningham JA. Little use of treatment among problem gamblers. Psychiatr Serv. 2005; 56:1024-5. [PubMed: 16088027]

182. Gainsbury S, Hing N, Suhonen N. Professional help-seeking for gambling problems: awareness, barriers and motivators for treatment. J Gambl Stud. 2013:1-17. [PubMed: 22138931]

183. Slutske WS, Jackson KM, Sher KJ. The natural history of problem gambling from age 18 to 29 . J Abnorm Psychology. 2003; 112:263.

184. Volberg RA, Gupta R, Griffiths MD, Olason DT, Delfabbro P. An international perspective on youth gambling prevalence studies. Int J Adolesc Med Health. 2010; 22:3-38. [PubMed: 20491416] 
185. Welte JW, Barnes GM, Tidwell M-CO, Hoffman JH. The association of form of gambling with problem gambling among American youth. Psychol Addict Behav. 2009; 23:105. [PubMed: 19290694]

186. LaPlante DA, Nelson SE, LaBrie RA, Shaffer HJ. Disordered gambling, type of gambling and gambling involvement in the British Gambling Prevalence Survey 2007. Eur J Public Health. 2011; 21:532-7. [PubMed: 19892851]

187. Grinols, EL. Gambling in America. Cambridge: Cambridge University Press; 2009. 